\title{
Effects of various mastitis treatments on the reproductive performance of cows
}

\author{
Sebastian Smulski ${ }^{1}$, Marek Gehrke ${ }^{2}$, Kacper Libera ${ }^{3 *}$, Adam Cieslak ${ }^{4}$, Haihao Huang ${ }^{4}$, Amlan Kumar Patra ${ }^{5}$ and \\ Malgorzata Szumacher-Strabel ${ }^{4}$
}

\begin{abstract}
Background: The purpose of the study described here was to evaluate the effects of different supportive treatments - such as antioxidants, immunomodulators, and nonsteroidal anti-inflammatory drugs (NSAIDs) - in mastitic cows treated with intramammary antibiotics on the efficacy of mastitis therapy and fertility indices. Fertility indices, including time to first insemination, conception rate, time between calving and conception (open days), and number of services per conception (insemination index), were evaluated for 300 dairy cows. Sixty cows without apparent clinical signs of mastitis were assigned 100 days after calving to a Control group. Another 240 cows with clinical mastitis were systematically divided into four experimental groups (I-IV) of 60 cows each. All mastitic cows were treated with approved intramammary antibiotics in recommended doses. Cows in Group I were treated with intramammary antibiotics only. Cows in Groups II, III, and IV, received intramammary antibiotic therapy and a single injection with antioxidants, an immunomodulator (lysozyme dimer), or an NSAID (flunixin meglumine), respectively.

Results: The lowest treatment efficacy of mastitic quarters and cows was noted in Group I (51.6 and 53.3\%; $p$ > 0.05). The best recovery rate was noted in Group II (63.3 and 66.7\%; $p>0.05$ ), followed by Group III (58.3 and 60.9\%) and Group IV (58.3 and 58.0\%; $p>0.05)$. The above data did not differ statistically $(p>0.05)$. The animals with mastitis (Groups I-IV) showed prolonged time to first insemination, more open days, higher insemination index, and lower conception rate than the control cows $(p<0.05)$. The conception rate of healthy cows and of successfully treated cows was insignificantly lower than that of cows required prolonged antibiotic therapy. Supportive treatments improved the mastitis recovery rate compared with intramammary antibiotics only. The efficacy of mastitis treatments affected the reproduction indices: in cows requiring prolonged treatment with antioxidants, a shorter time to first insemination was needed than in other groups $(p<0.05)$. Fewer days open were observed between the group with antioxidants and the control group $(p<0.05)$.

Conclusions: Clinical mastitis negatively affects reproductive indices (days open, pregnancy rate after first Al, NSC) in dairy cows. Different types of supportive medicine, such as antioxidants (vitamin $C$ and $E$, and $\beta$-carotene), lysozyme dimer, or NSAID can be useful in improving fertility in mastitis cows treated with antibiotic only. It has been proven that each supportive treatment improved antibiotics efficiency and the antibiotic combined with the antioxidants was the most effective treatment.
\end{abstract}

Keywords: Mastitis, Cows, Reproduction indices

\footnotetext{
* Correspondence: kliberaa@gmail.com

${ }^{3}$ Department of Preclinical Sciences and Infectious Diseases, Faculty of

Veterinary Medicine and Animal Science, Poznań University of Life Sciences,

Wolynska 35, 60-637 Poznan, Poland

Full list of author information is available at the end of the article
}

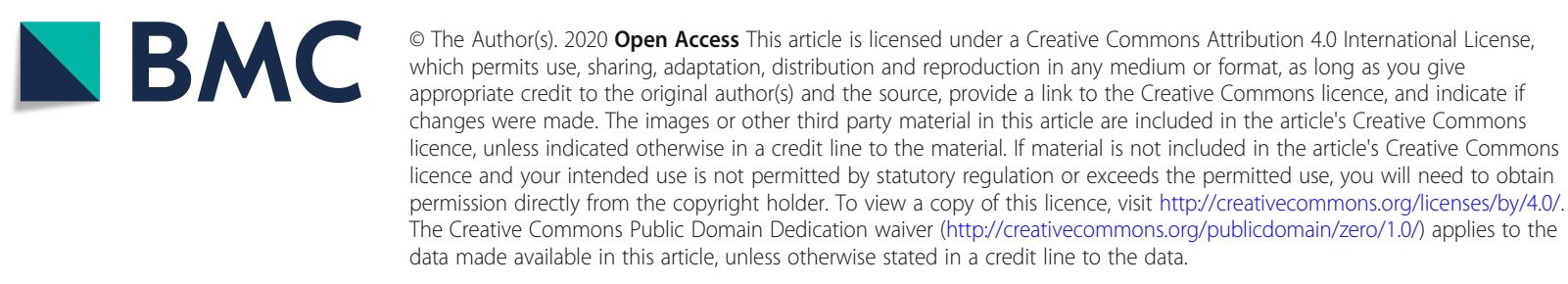




\section{Background}

Researchers are concerned about reduced reproductive performance in dairy cattle simultaneously with decreased milk yield. The antagonism between fertility and overall milk production has been emphasized by many authors who have examined production and fertility indicators over the years in the same herd [1-3]. For example, in the 1970s, the conception rate after first artificial insemination (AI) was between 50 and $60 \%$; this has now declined to $35-45 \%$ due to increased milk yield $[4,5]$. Knowledge of cattle reproduction and herd management has been improved in recent decades [6, 7]. Decreased fertility may be caused by management failures, indigestion, and metabolic disorders, which result from poor quality dietary components or negative energy balance, as well as from genetic selection focused mainly on milk yield [8].

The negative effect of subclinical and clinical form of mastitis on fertility and ovary functionality of cows has been well documented $[9,10]$. Reactive oxygen species (ROS) released during mastitis development negatively affect reproductive systems, being responsible for decreased progesterone production and induced apoptosis of corpus luteum (CL) cells, resulting in adverse effects on oocytes $[11,12]$. Physiological luteolysis is also caused by CL epithelium cells and is linked to the ROS produced by these cells. It is supposed that the ROS take part in local processes responsible for luteolysis [13]. Proinflammatory cytokines are released during inflammation, which stimulates the production of ROS and activates phospholipase A2, leading to luteolysis [14].

Moore et al. [15] suggested that clinical mastitis (CM) exerts an indirect impact on fertility by modifying the interestrus period and shortening luteal phase. Cows diagnosed with $\mathrm{CM}$ in the period from calving to first breeding were characterized by prolonged days open and more inseminations required for conception than were healthy animals. Santos et al. [16] stated that the occurrence of $\mathrm{CM}$ in the period from the first insemination decreased the efficiency of this procedure and lowered the conception ratio (CR), as well as increasing culling and the percentage of embryo deaths and abortion. According to Schrick et al. [10], not only can CM lead to delayed first insemination, extended days open, and more AI needed for conception, but the subclinical form also has significant effects. A meta-analysis conducted by Fourichon et al. [17] with data collected over several decades concluded that retained placenta, ovarian cysts, and metabolic disorders affect cows' fertility. Other researchers have also evaluated the effects of mastitis on fertility, but no information about any coexisting disorders was presented [10, 16]. These researchers suggested that either udder inflammation as isolated process or mastitis as process, combined with other disorders, could negatively affect fertility. The main research objectives of this study were thus to 1 ) study the association between the time of occurrence of CM (expressed in days in milk; DIM) and the reproductive performance of the cows under commercial farm conditions; 2) to assess the impact of different protocols of supportive mastitis therapy on reproductive performance, udder inflammation treatment efficiency, and total antioxidant status (TAS) of peripheral blood during mastitis.

\section{Results}

A total of 238 cows were diagnosed with clinical mastitis, with 283 quarters affected. Two cows were remove from the experiment due to the presence of yeasts or Prothoteca spp. in milk.

The prevalence of the most significant pathogens isolated from milk (Streptococcus sp. and Staphylococcus aureus) was similar in all treatment groups (Table 1). Only the percentage of milk samples with $S$. aureus was lower in group IV (-antibiotic +NSAID), though this was not a statistically significant difference. However, no better effects of mastitis treatment were observed in this group.

After the initial antimicrobial treatment, $60.1 \%$ of quarters (58.4\% of cows) had recovered. Prolonged treatment was essential for $39.9 \%$ of quarters ( $41.6 \%$ of cows). The most effective initial therapy (with recovery of $66.7 \%$ of quarters) was observed in the group receiving both antibiotics and antioxidants (Table 2). Administration of the immunomodulator led to recovery in $60.9 \%$ of quarters (58.3\% of cows) and the NSAID treatment resulted in recovery in $58 \%$ of quarters (58.3\% of cows). The group treated with intramammary tubes alone saw the lowest recovery rate, at $53.3 \%$ of quarters $(51.6 \%$ of cows). The differences between the groups were not statistically significant $(p>0.05$; Table 1$)$.

\section{Effect of mastitis on fertility}

Reproductive performance indices in the cows suffering from $\mathrm{CM}$ were significantly poorer than in the healthy cows (Table 3). Differences in the number of days open were also observed among those cured after the first treatment, those cured after prolonged treatment, and the control group $(p<0.05)$. Differences were observed between the member of Groups I (antibiotic only) and II (antibiotic with antioxidants) who required an additional treatment of antibiotics. Additionally, the time to first AI (days) was longer in the experimental groups than in the control group $(p<0.05)$. Cows requiring prolonged antioxidant treatment had a shorter time in days to first insemination than those in other groups requiring additional prolonged antibiotics treatment $(p<0.05)$. On the other hand, statistical differences for all treatment groups for the number of services per conception were not observed. In experimental antibiotic groups, there were 31 days open more compared to control group $(p<0.05)$. Those cows for whom first therapy or prolonged treatment was essential 
Table 1 Bacteria isolated from infected quarters (no statistical differences were noted)

\begin{tabular}{|c|c|c|c|c|c|}
\hline Treatment & $\begin{array}{l}\text { Str. sp. } \\
n^{1}(\%)\end{array}$ & $\begin{array}{l}\text { S. aureus } \\
\mathrm{n}^{1}(\%)\end{array}$ & $\begin{array}{l}\text { CNS } \\
n^{1}(\%)\end{array}$ & $\begin{array}{l}\text { G- } \\
n^{1}(\%)\end{array}$ & $\begin{array}{l}\text { Others }^{\mathrm{a}} \\
\mathrm{n}^{1}(\%) \\
\end{array}$ \\
\hline Group I (antibiotic) & $32(43.2)$ & $16(21.6)$ & $11(14.9)$ & $13(17.6)$ & $2(2.7)$ \\
\hline Group II (antibiotic + antioxidants) & $29(40.3)$ & $17(23.6)$ & $15(20.8)$ & $9(12.5)$ & $2(2.8)$ \\
\hline Group III (antibiotic + lysozyme dimer) & $30(43.5)$ & $15(21.7)$ & $12(17.4)$ & $11(15.9)$ & $1(1.4)$ \\
\hline Group IV (antibiotic + NSAID) & $30(44.1)$ & $8(11.8)$ & $15(22.1)$ & $9(13.2)$ & $6(8.8)$ \\
\hline Total & $121^{2}(42.7)$ & $56^{2}(19.7)$ & $53^{2}(18.7)$ & $42^{2}(14.8)$ & $11^{2}(3.8)$ \\
\hline
\end{tabular}

${ }^{a}$ no growth, mixed infection, or other Gram-positive bacteria

CNS Coagulase-negative staphylococci

G- Gram-negative bacteria

${ }^{1}$ Percentage of isolated bacteria to microorganisms isolated in group

${ }^{2}$ Percentage of all isolated microorganism

were characterized by more days open than the control group (average 24 days and 44.1 days more, respectively; $p<0.05$ ). Cows cured after first or prolonged treatment showed more days to first $\mathrm{AI}$ and more days open than the control $(p<0.05$; Table 3). Statistical differences were also observed between prolonged treatment with antibiotic + lysozyme dimer, prolonged treatment with antibiotic + NSAID, and the control group (41.7 and 43.5 respectively, $p<0.05$ ). Those cows receiving additional treatment had fewer days to first AI and fewer days open, but the difference was not statistically significant.

Considering the effectiveness of the therapy, a higher number of services per conception (by 0.9 ) was noted in cows receiving prolonged therapy than in the control group $(p<0.05)$. Moreover, the highest number of services per conception (NSC) was observed in the group with prolonged therapy combined with injection of the lysozyme dimer $(2.7 \pm 1.3)$. Lower NSC was observed in the group treated repeatedly with antibiotics alone $(2.4 \pm$ 1.3). Statistical differences were observed only in NSC compared with the control group $(p<0.05)$. The average value of NSC in the groups treated with single antimicrobial therapy alone, in comparison to the groups treated with antioxidants, was similar $(1.8 \pm 0.8$ and $1.8 \pm 0.9$, respectively). In addition, NSC data from the antibiotic + lysozyme dimer and antibiotic + NSAID groups were slightly better $(1.7 \pm 0.8$ and $1.6 \pm 1.1$, respectively).
A higher number of services per conception was observed in the experimental groups than in the control cows. However, the differences between those cured by the first treatment and those only recovering after prolonged treatment were not statistically significant.

On the other hand, the pregnancy rate after first AI and NSC depending on timing of mastitis did not differ $(p>0.05)$ (Table 4). Statistical differences were observed in terms of days open between cows with mastitis detected between 85 and 100 days after calving and mastitis detected earlier $(0-21,22-42,43-63$, and 64-84).

Only $20 \%$ of the cows who recovered from mastitis (the experimental group) became pregnant after the first AI within 70 days after parturition (average at $56.5 \pm 6.3$ day postpartum; Table 5 ). In the control group, there was a higher pregnancy rate after the first AI $(43 \% ; p<0.05)$ on day 70 after parturition, with comparable AI timing $(60.5 \pm$ 6.7 days). The best results in the time to the first effective AI were observed in those treated with antioxidants. The proportion of cows that became pregnant within 70-90 days postpartum was comparable in both groups $(33 \%$ in the group with mastitis and $30 \%$ in the control group). More cows become pregnant over 90 days after parturition in the experimental groups (50\%) than in the control group (23\%). The average number of days from calving to first AI was comparable in both groups of cows that became pregnant between 70 and 90 days postpartum ( $81.1 \pm 6.1$ days/

Table 2 Effects of supportive therapy on the effectiveness of mastitis treatment

\begin{tabular}{|c|c|c|c|c|}
\hline \multirow[t]{2}{*}{ Treatment } & \multicolumn{2}{|l|}{$\mathrm{FT}$} & \multicolumn{2}{|l|}{ PRO } \\
\hline & $\begin{array}{l}\mathrm{n} \\
\text { Cows (Qr) }\end{array}$ & $\begin{array}{l}\% \\
\text { Cows (Qr) }\end{array}$ & $\begin{array}{l}\mathrm{n} \\
\text { Cows (Qr) }\end{array}$ & $\begin{array}{l}\% \\
\text { Cows (Qr) }\end{array}$ \\
\hline Group I (antibiotic) & $31(40)$ & $51.6(53.3)$ & $28(34)$ & $47.4(45.9)$ \\
\hline Group II (antibiotic + antioxidants) & $38(48)$ & 63. (66.7) & $22(24)$ & $36.6(33.3)$ \\
\hline Group III (antibiotic + lysozyme) & $35(42)$ & $58.3(60.9)$ & $25(27)$ & $41.6(39.1)$ \\
\hline Group IV (antibiotic + NSAID) & $35(40)$ & $58.3(58.0)$ & $24(28)$ & $40.6(41.1)$ \\
\hline Total & $139(170)$ & $58.4(60.1)$ & 99 (113) & $41.6(39.9)$ \\
\hline
\end{tabular}

FT First treatment, PRO Prolonged treatment, NSAID Nonsteroidal anti-inflammatory drugs, Qr Quarters

${ }^{1}$ No statistical differences were noted among the groups 
Table 3 The effect of supportive therapy on time to first artificial insemination (Al), days open (DO) and service index per conception (S/C)

\begin{tabular}{|c|c|c|c|c|c|c|c|c|c|c|c|c|}
\hline \multirow{2}{*}{$\frac{\text { Group }}{\text { Control }}$} & \multirow{2}{*}{$\frac{n}{60}$} & \multicolumn{3}{|l|}{$\mathrm{Al}$} & \multirow{2}{*}{$\frac{n}{60}$} & \multicolumn{3}{|l|}{ DO } & \multirow{2}{*}{$\frac{n}{60}$} & \multicolumn{3}{|l|}{$S / C$} \\
\hline & & $78.5^{c}$ & \pm & $20.9^{m, z, c}$ & & 88.8 & \pm & $27.4^{n, z, c}$ & & 1.4 & \pm & $0.6^{m, z, c}$ \\
\hline Antibiotics & 157 & 92.4 & \pm & $27.1^{y}$ & 157 & 119.8 & \pm & $43.7^{y}$ & 157 & 1.9 & \pm & $1.0^{y}$ \\
\hline First treatment & 92 & 90.2 & \pm & $25.8^{k}$ & 102 & 112.8 & \pm & $38.2^{m}$ & 102 & 1.7 & \pm & $0.9^{m}$ \\
\hline Prolonged treatment & 65 & 95.6 & \pm & $28.8^{k}$ & 54 & 132.9 & \pm & $50.3^{k}$ & 54 & 2.3 & \pm & $1.1^{k}$ \\
\hline \multicolumn{13}{|l|}{ First treatment } \\
\hline Antibiotic & 20 & 102.6 & \pm & $28.9^{a b}$ & 25 & 130.1 & \pm & $37.5^{a b}$ & 25 & 1.8 & \pm & $0.8^{a b c}$ \\
\hline Antibiotic + antioxidants & 25 & 78.6 & \pm & $21.9^{c}$ & 25 & 99.16 & \pm & $34.6^{b c}$ & 25 & 1.8 & \pm & $0.9^{a b c}$ \\
\hline Antibiotic + lysozyme dimer & 23 & 82.0 & \pm & $24.6^{b c}$ & 24 & 101.8 & \pm & $27.5^{b c}$ & 24 & 1.7 & \pm & $0.8^{b c}$ \\
\hline Antibiotic +NSAIDs & 25 & 99.5 & \pm & $20.3^{a b c}$ & 28 & 118.9 & \pm & $43.5^{a b c}$ & 28 & 1.6 & \pm & $1.1^{b c}$ \\
\hline \multicolumn{13}{|l|}{ Prolonged treatment } \\
\hline Antibiotic & 21 & 108.9 & \pm & $31.4^{a}$ & 16 & 155.7 & \pm & $64.8^{a}$ & 16 & 2.4 & \pm & $1.3^{a b}$ \\
\hline Antibiotic + antioxidants & 14 & 80.6 & \pm & $23.5^{b c}$ & 14 & 109.3 & \pm & $46.7^{b c}$ & 14 & 1.9 & \pm & $0.9^{a b c}$ \\
\hline Antibiotic + lysozyme dimer & 14 & 89.3 & \pm & $29.5^{a b c}$ & 13 & 130.5 & \pm & $43.0^{a b}$ & 13 & 2.7 & \pm & $1.3^{a}$ \\
\hline Antibiotic +NSAIDs & 15 & 97.1 & \pm & $23.1^{a b c}$ & 12 & 132.3 & \pm & $26.0^{a b}$ & 12 & 2 & \pm & $0.6^{a b c}$ \\
\hline SEM & & 1.78 & & & & 2.86 & & & & 0.06 & & \\
\hline \multicolumn{13}{|l|}{$P$ value } \\
\hline \multicolumn{2}{|c|}{ Control vs. first and prolonged treatments $(k, m, n)$} & \multicolumn{4}{|l|}{0.001} & \multicolumn{4}{|l|}{$<0.001$} & \multicolumn{3}{|c|}{$<0.001$} \\
\hline \multicolumn{2}{|l|}{ Control vs. antibiotics $\left({ }^{y, z}\right)$} & \multicolumn{4}{|l|}{$<0.001$} & \multicolumn{4}{|l|}{$<0.001$} & \multicolumn{3}{|c|}{$<0.001$} \\
\hline \multicolumn{2}{|l|}{ Control vs. treatments $(a, b, c)$} & \multicolumn{4}{|c|}{$<0.001$} & \multicolumn{4}{|l|}{$<0.001$} & \multicolumn{3}{|c|}{$<0.001$} \\
\hline
\end{tabular}

$n$ Number of observations, SEM Standard error of mean

Superscripts $k, m, n$ in the same column indicate significantly different between control versus first treatment and prolonged treatment $(P<0.05)$

Superscripts $y, z$ in the same column indicate significantly different between control versus antibiotics $(P<0.05)$

Superscripts $a, b, c$ in the same column indicate significant different between control versus treatment groups $(P<0.05)$

group with mastitis; $81.4 \pm 6.1$ days/group of healthy cows) and later (113.2 \pm 20.2 days/group with mastitis; $107.6 \pm$ 16.4 days/group of healthy cows; $p>0.05$ ). A tendency was observed for CR and NSC to be lower when mastitis was diagnosed close in time to breeding, though the data did not differ statistically.

We investigated the association between the timing of mastitis and the timing of AI and its efficiency. Table 6 show that all experimental cows were divided into eight groups based on the timing of mastitis in relation to the timing of first AI, and the calculated probability of conception for each group.

The relation between mastitis and total antioxidant status Table 7 shows the fluctuations in the total antioxidant status on days 0 and 7 from the onset of therapy, and the difference between the results on these 2 days.

Table 4 Timing of mastitis and its effect on pregnancy rate after the first artificial insemination (Al), number of services per calving (NSC), and days open

\begin{tabular}{|c|c|c|c|c|}
\hline Time of mastitis (days postpartum) & $n$ & Pregnancy rate after first Al (\%) & NSC & Days open $(d)$ \\
\hline$\overline{0-21}$ & 89 & 70.0 & 1.7 & $110.7^{b}$ \\
\hline $22-42$ & 22 & 66.7 & 2.0 & $113.3^{b}$ \\
\hline $43-63$ & 22 & 63.0 & 1.8 & $120.7^{b}$ \\
\hline $64-84$ & 14 & 62.5 & 2.0 & $128.2^{a b}$ \\
\hline $85-100$ & 5 & 50.0 & 2.7 & $160.3^{a}$ \\
\hline Total/average mastitis cows & 152 & 66.9 & 1.8 & 116.1 \\
\hline SEM & & 2.33 & 0.07 & 3.0 \\
\hline$P$-value & & 0.44 & 0.13 & 0.013 \\
\hline
\end{tabular}

$n$ Number of observations, Al Artificial insemination, NSC Number of services per calving

Different superscripts in the same column indicate significant difference $(p<0.05)$ 
Table 5 Number of cows with average number (and percent) of days to first artificial insemination in different groups

\begin{tabular}{|c|c|c|c|c|c|c|c|}
\hline \multirow{3}{*}{$\begin{array}{l}\text { Group } \\
\text { Control }\end{array}$} & \multicolumn{7}{|l|}{$\mathrm{Al}(\mathrm{d})$} \\
\hline & \multicolumn{3}{|l|}{$<70 \mathrm{~d}$} & \multicolumn{2}{|l|}{$70-90 \mathrm{~d}$} & \multicolumn{2}{|l|}{$>90 \mathrm{~d}$} \\
\hline & $60.5^{a, j}$ & \pm & 6.7 & $81.5 \pm$ & 6.1 & $107.6 \pm$ & 16.4 \\
\hline & 26 & & $43 \%$ & 20 & $33 \%$ & 14 & $23 \%$ \\
\hline \multirow[t]{2}{*}{ Experimental } & $56.5^{k}$ & \pm & 6.3 & $81.1 \pm$ & 6.1 & $113.2 \pm$ & 20.2 \\
\hline & 31 & & $20 \%$ & 47 & $30 \%$ & 79 & $50 \%$ \\
\hline \multirow[t]{2}{*}{ Antibiotic } & $61.3^{\mathrm{ab}}$ & \pm & 5.1 & $82.7 \pm$ & 5.9 & $121.0 \pm$ & 24.9 \\
\hline & 4.0 & & $9 \%$ & 10.0 & $23 \%$ & 27 & $63 \%$ \\
\hline \multirow{2}{*}{$\begin{array}{l}\text { Antibiotic + } \\
\text { antioxidants }\end{array}$} & $54.4^{b}$ & \pm & 6.0 & $82.3 \pm$ & 5.6 & $103.5 \pm$ & $=11.5$ \\
\hline & 14 & & $36 \%$ & 12 & $31 \%$ & 13 & $33 \%$ \\
\hline \multirow{2}{*}{$\begin{array}{l}\text { Antibiotic + } \\
\text { lysozyme }\end{array}$} & $58.8^{\mathrm{ab}}$ & \pm & 7.2 & $79.7 \pm$ & 6.4 & $113.5 \pm$ & $=20.3$ \\
\hline & 12 & & $32 \%$ & 12 & $32 \%$ & 13 & $35 \%$ \\
\hline \multirow{2}{*}{$\begin{array}{l}\text { Antibiotic } \\
+ \text { NSAID }\end{array}$} & $60.3^{\mathrm{ab}}$ & \pm & 9.5 & $82.1 \pm$ & 5.3 & $110.0 \pm$ & $=15.7$ \\
\hline & 3 & & $8 \%$ & 11 & $30 \%$ & 26 & $70 \%$ \\
\hline \multirow[t]{2}{*}{ Total } & 58.4 & \pm & 6.7 & $81.2 \pm$ & 6.0 & $112.4 \pm$ & 19.7 \\
\hline & 57 & & $26 \%$ & 67 & $31 \%$ & 93 & $43 \%$ \\
\hline SEM & 0.89 & & & 0.74 & & 2.05 & \\
\hline \multicolumn{8}{|l|}{$P$ value } \\
\hline $\begin{array}{l}\text { Control vs. } \\
\text { experimental }(\mathrm{j}, \mathrm{k})\end{array}$ & 0.026 & & & 0.84 & & 0.33 & \\
\hline Control vs. groups $(\mathrm{a}, \mathrm{b})$ & 0.066 & & & 0.59 & & 0.057 & \\
\hline
\end{tabular}

A slight increase in total antioxidant status (TAS) was observed in all groups on day 7 compared to day 0 . The differences oscillated between 0.14 and $0.22 \mathrm{mM} / \mathrm{L}$ and did not differ significantly. There were significant differences in the dynamic of TAS changes from day 0 to 7 between the healthy and the prolonged groups. In conclusion, TAS fluctuations did not show any differences in data on day 0 and 7 of treatment, and would not reflect the relationship between the clinical assessment of the occurrence of mastitis and its therapeutic efficiency.

Table 6 Probability of conception after first Al, depending on timing of mastitis

\begin{tabular}{|c|c|c|c|}
\hline${ }^{1}$ Group (n total = 213): & $\begin{array}{l}{ }^{2} \text { Probability of } \\
\text { conception: }\end{array}$ & $P$-value & $\mathrm{n}$ \\
\hline Mastitis until 90 days before $\mathrm{Al}$ & 0.97 & 0.92 & 169 \\
\hline Mastitis until 60 days before $\mathrm{Al}$ & 0.78 & 0.39 & 100 \\
\hline Mastitis until 30 days before $\mathrm{Al}$ & 0.63 & 0.25 & 34 \\
\hline Mastitis until 20 days before Al & 0.67 & 0.43 & 20 \\
\hline Mastitis until 15 days before $\mathrm{Al}$ & 0.66 & 0.44 & 17 \\
\hline Mastitis until 10 days before $\mathrm{Al}$ & 0.60 & 0.44 & 11 \\
\hline Mastitis until 5 days before $\mathrm{Al}$ & 0.39 & 0.21 & 10 \\
\hline $\begin{array}{l}\text { Mastitis diagnosed either on day of } \mathrm{Al} \text { or } \\
15 \text { days after } \mathrm{Al}\end{array}$ & $<0.001$ & 0.009 & 7 \\
\hline
\end{tabular}

${ }^{1}$ Mean day of occurrence of mastitis before Al (30.0 \pm 29.0$)$; mean day of first Al $(93.8 \pm 27.9)$

${ }^{2}$ Calculation based on logistic regression analysis

\section{Discussion}

The effectiveness of mastitis therapy in this study fluctuated between 51.6 and $63.3 \%$ and was comparable to, or slightly lower than, the effectiveness of the therapy conducted by other authors. Milne et al. [18] reported that the efficiency of treatment of mastitis caused by streptococci was approximately 49\%. In contrast, Malinowski et al. [19] noted that antibiotic therapy based on penicillin and neomycin had an effectiveness of $50 \%$, and that amoxicillin with clavulanic acid and cefalexine with a single injection of lysozyme dimer had as much as $80 \%$ effectiveness against microorganisms such as S. agalactiae, S. uberis, E. coli, and S. dysgalactiae. In the present study, the lowest treatment efficiency was observed in the control mastitis group (51.6\%), and the highest treatment efficiency was seen in the group treated with antioxidants (63.3\%). The data did not differ significantly $(p=0.09)$. The literature has described the positive effect of antioxidants in mastitis therapy. Injections of vitamins $\mathrm{C}$, E, and selenium 3 weeks before parturition increased total antioxidant status until 4 weeks after calving [20]. Moreover, supplementation with vitamin C decreased somatic cell counts in milk [21]. Betacarotene is responsible for maintaining immunological functions, and can thus decrease incidences of mastitis and retained placenta [22]. Plasma beta-carotene concentration tended to be lowest in the first week after calving [23]. The reason for the better effectiveness of antibiotic therapy combined with vitamin $\mathrm{E}$ could be the positive correlation with increased chemotactic abilities in granulocytes. Oral and parenteral supplementation of this vitamin, when its serum plasma concentration reaches its nadir in the first 2 weeks after calving, can improve phagocytosis in blood granulocytes [24]. These results may indicate immunosuppression after calving, possibly due to decreased feed intake efficiency; this justifies the use of antioxidants in the period after calving.

The effectiveness of antibiotic treatment combined with lysozyme dimer was $58.3 \%$, comparable with that of other methods of supportive therapy. The efficiency of this supportive treatment did not differ from its value in earlier experiments, where the antibiotic was used independently, and the effectiveness of therapy oscillated between 43.5 and $74.1 \%$. In the study of Malinowski et al. [25], a single injection of lysosome dimer increased treatment effectiveness by $8.7 \%$. In the present study, the use of lysozyme dimer increased the therapeutic efficiency by $6.7 \%$, compared with the control mastitis group. However, the difference was not statistically significant $(p=0.36)$. The increased effectiveness of antibiotic therapy combined with lysozyme dimer in mastitis treatment has been observed in cows vaccinated against staphylococcus infections [26]. Malinowski et al. [25] noted a reduction in subclinical, bacterial, and nonbacterial udder inflammation cases after intravenous injection of lysozyme dimer. 
Table 7 Total antioxidant status of blood (mM/L) on days 0 and 7 after mastitis diagnosis (mean \pm SD)

\begin{tabular}{|c|c|c|c|c|c|c|c|c|c|c|}
\hline Group & $n$ & 0 & & & 7 & & & TAS cha & & \\
\hline Control & 15 & 0.17 & \pm & 0.07 & 0.15 & \pm & $0.10^{\mathrm{ab}}$ & -0.02 & \pm & $0.09^{j}$ \\
\hline Cured & 26 & 0.16 & \pm & 0.08 & 0.22 & \pm & 0.10 & 0.07 & \pm & $0.10^{k}$ \\
\hline Antibiotic +NSAID & 8 & 0.14 & \pm & 0.06 & 0.15 & \pm & $0.06^{\mathrm{ab}}$ & 0.01 & \pm & 0.11 \\
\hline Antibiotic + antioxidants & 9 & 0.19 & \pm & 0.10 & 0.29 & \pm & $0.05^{\mathrm{a}}$ & 0.10 & \pm & 0.08 \\
\hline Antibiotic + lysozyme & 9 & 0.14 & \pm & 0.06 & 0.21 & \pm & $0.12^{\mathrm{ab}}$ & 0.07 & \pm & 0.11 \\
\hline Prolonged & 19 & 0.14 & \pm & 0.11 & 0.20 & \pm & 0.11 & 0.06 & \pm & $0.16^{k}$ \\
\hline Antibiotic +NSAID & 7 & 0.12 & \pm & 0.07 & 0.12 & \pm & $0.11^{b}$ & 0.01 & \pm & 0.13 \\
\hline Antibiotic + antioxidants & 6 & 0.15 & \pm & 0.19 & 0.28 & \pm & $0.08^{\mathrm{a}}$ & 0.14 & \pm & 0.23 \\
\hline Antibiotic + lysozyme & 7 & 0.14 & \pm & 0.06 & 0.19 & \pm & $0.09^{\mathrm{a}}$ & 0.05 & \pm & 0.08 \\
\hline Total & 60 & 0.15 & \pm & 0.09 & 0.19 & \pm & 0.11 & 0.04 & \pm & 0.12 \\
\hline SEM & & 0.011 & & & 0.014 & & & 0.016 & & \\
\hline \multicolumn{11}{|l|}{$P$ value } \\
\hline \multicolumn{2}{|l|}{ Control vs. cured and prolonged (j,k) } & \multicolumn{3}{|l|}{0.55} & \multicolumn{3}{|l|}{0.12} & \multicolumn{3}{|l|}{0.07} \\
\hline \multicolumn{2}{|l|}{ Control vs. treated groups ${ }^{(a ; b)}$} & \multicolumn{3}{|l|}{0.77} & \multicolumn{3}{|l|}{$<0.01$} & \multicolumn{3}{|l|}{0.08} \\
\hline
\end{tabular}

SEM Standard error of means, TAS changes Total antioxidant changes from day 0 to 7

Different symbols for condition (control vs. cured and prolonged treatments $[\mathrm{j}, \mathrm{k}]$ ) and groups (control As. treated groups [a,b]) are indicated as significant differences $(P<0.05)$

In our experimental groups, the lowest efficacy of treatment was observed in the group of cows treated with the NSAID flunixin meglumine (58.3\% of cows, $58 \%$ of quarters). The results of treatment were numerically higher (by $6.7 \%$ in cows and $4.7 \%$ in quarters) only than in the group of cows successfully treated with intramammary antibiotic only $(p=0.57)$. No improvement in antibiotic treatment combined with flunixin meglumine was described by Green et al. [27]. However, NSAID led to decreased body temperature with clinical signs of fever and reduced clinical signs of inflammation, especially in colimastitis [28]. Flunixin meglumine blocks the synthesis of PGF2 $\alpha$, which may have an effect on reproductive performance in cows with mastitis [29].

Fertility indicators did not differ significantly from the results obtained in other studies [16, 30]. The average number of days since parturition to first AI was $90.2 \pm 25.8$ days for cows cured after first treatment and $95.6 \pm 28.8$ days for cows needed prolonged therapy. The timing and variety of first AI date were similar to those obtained by Barker et al. [31]. In other studies [10, 16, 30], the time to first AI was shorter (66.0 to 77.3 days). Days open in the present study fell between 88.8 and 132.9 days, and was comparable with the result obtained by Schrick et al. [10] and Barker et al [31]. However, less promising results of 165 days open have been reported in another study [16]. In our study, the average number of services per conception was 1.4-2.3, which was similar to the results of other studies [10,30].

The results suggest that the occurrence of mastitis 710 days before AI decreases insemination effectiveness. Most likely, prolonged treatment for more than 7-10 days and the on-going inflammation process (due to the low efficiency of microbial therapy or lack of supportive treatment) is the cause of this of negative influence of mastitis on fertility. Our results are coherent with those of Barker et al. [31] and Santos et al. [16], who also noted a negative impact of mastitis either before or after AI on the number of days open. An increased culling rate among cows with mastitis close to AI, as well as the high proportion of embryo deaths, were also reported [16, 31]. Moreover, Ahmadzadeh et al. [30] noted longer open periods and higher insemination index in those cows in whom mastitis occurred between 56 and 105 days in milk and over 105 days in milk, as compared to cows with clinical signs of udder inflammation before 56 days postpartum. This study suggests that the occurrence of mastitis in the period close to AI has a clearer negative impact on fertility than does its occurrence in the early post calving period.

Considering the results of TAS in relation to treatment effectiveness, statistical differences were noted between the group with antioxidants who recovered after the first treatment in comparison to the group treated with prolonged therapy and NSAID. TAS values in all groups were comparable to those of other studies [32]. Analyzing TAS values does not seem to help assess either the intensity of inflammatory process or treatment efficiency. However, the administration of antioxidants in mastitis therapy results in increased effectiveness of the therapy, as has been confirmed in other studies through determination of TAS. This allows the negative impact of local inflammatory processes on fertility to be reduced [33]. Furthermore, when comparing these data, the conclusion could be drawn that the effectiveness of AI performed several days after the 
occurrence of mastitis may be reduced, and the high coefficient of determination confirms this. Thus, there is strong convergence between the curve and the calculated probability of conception.

\section{Conclusion}

Considering the effect of the timing of mastitis after parturition on reproductive performance, the conclusion could be drawn that cows with udder inflammation during the first hundred days postpartum are characterized by longer time to first insemination, more days open, and a higher number of services per conception. Ineffective first antibiotic therapy can negatively affect the number of days open. The use of an additional single injection of antioxidants can improve the effectiveness of antibiotic treatment of mastitis, as well as the reproduction indices analyzed here.

\section{Methods}

Three commercial dairy farms located in the middle of Poland were enrolled in this study. Management status of all enrolled farms was similar, being based on the free stall system. The average number of cows on each farm was approximately 300 , with an average milk yield of about 7000 $\mathrm{kg} / \mathrm{lactation}$. A total of 240 dairy cows with the acute form of mastitis (hot and swollen udder, as well as macroscopic changes in milk, such as clots and watery discharge)-excluding cows with toxic mastitis (i.e., with systemic symptoms such as fever, recumbency, and retained fetal membranes)- were selected for this experiment. In the enrolled animals, CM was diagnosed from day 10 after parturition to day 14 after the first AI. Another 60 healthy cows were also allocated to this study. All these cows were divided into five groups, with four treatment groups and one control group (Table 8). On each farm, eighty mastitic cows (in four groups with twenty cows in each group) and twenty healthy cows were used. The treatment of mastitic cows in Groups I, II, III, and IV began immediately after the clinical diagnosis of mastitis. All mastitic cows were treated with approved intramammary antibiotic products. Intramammary tubes with proven antibiotic sensitivity

Table 8 Groups of cows and their treatment methods

\begin{tabular}{|c|c|c|}
\hline Group & Cow condition (n) & Treatment method \\
\hline I & Acute mastitis (60 cows) & Intramammary antibiotics only \\
\hline$\|$ & Acute mastitis (60 cows) & $\begin{array}{l}\text { Intramammary antibiotics }+ \\
\text { antioxidants (subcutaneous } \\
\text { injection) }\end{array}$ \\
\hline III & Acute mastitis (60 cows) & $\begin{array}{l}\text { Intramammary antibiotics + } \\
\text { immunomodulator (one } \\
\text { intra-muscular injection) }\end{array}$ \\
\hline IV & Acute mastitis (60 cows) & $\begin{array}{l}\text { Intramammary antibiotics }+ \\
\text { nonsteroidal anti-inflammatory } \\
\text { drug (one intramuscular injection) }\end{array}$ \\
\hline V & Healthy (60 cows) & Control group: not treated \\
\hline
\end{tabular}

(according to our laboratory tests) were used as recommended by the manufacturers. Cobactan (cefquinome sulfate $25 \mathrm{mg} / 1 \mathrm{ml}$; Intervet, Boxmeer, Netherlands) in farm A, Lincocin forte (lincomycin hydrochloride $330 \mathrm{mg} / 10$ $\mathrm{ml}$, neomycin sulfate $100 \mathrm{mg} / 10 \mathrm{ml}$; Pfizer, Animal Health, Belgium) in farm B, and Synulox (amoxicilin trihydrate $140 \mathrm{mg} / \mathrm{ml}$, clavulanic acid $35 \mathrm{mg} / \mathrm{ml}$, prednisolone $10 \mathrm{mg} /$ $\mathrm{ml}$ Pfizer, Animal Health, UK) in farm $\mathrm{C}$ were used. All these intramammary antibiotic tubes were administrated three times every 12 hours. Additional supportive treatments were applied once, such as a single-shot intramuscular injection on the first day of antibiotic therapy. The following supportive preparations were used:

- antioxidants: vitamin C (Vitaminum C, Biowet Pulawy) at a dose of $0.01 \mathrm{mg} / \mathrm{kg}, \beta$-carotene (Carofertin $10 \mathrm{mg} / \mathrm{ml}$, Alverta u. Wertfft) at a dose of $0.5 \mathrm{mg} /$ $\mathrm{kg}$, vitamin E and Se (vitamin E 50 + Se Pro Inj) at doses of $1 \mathrm{mg} / \mathrm{kg}$ of vitamin $E$ and $0.01 \mathrm{mg} / \mathrm{kg}$ of Se.

- immunomodulator: lysozyme dimer $(5.0 / 10 \mathrm{ml}$ Lydium-KLP, Nika Health Products) at a dose of $0.02 \mathrm{mg} / \mathrm{kg}$

- NSAID: flunixin meglumine $(50 \mathrm{mg} / \mathrm{ml}$ Flunimeg, Scanvet) at a dose of $2.2 \mathrm{mg} / \mathrm{kg}$.

Milk samples were taken from cows with clinical mastitis without systemic signs and symptoms. Cows with acute mastitis were recognized by experienced veterinarians, who did not know the study design; the experiment was thus blinded. Clinical cases of udder inflammation manifested with hot and swollen mammary gland, abnormalities in milk (clots and watery discharge), decreased milk production, and positive California Mastitis Test (Mastirapid, Vetoquinol, France). Milk samples were collected before treatment and after cleaning the teats, discarding a few streams of milk and scrubbing the teat ends with cotton balls moistened with $70 \%$ alcohol. Medicines were injected on the first day of therapy by another group of veterinarians.

Clinical mastitis was diagnosed from day 10 in milk to day 14 after the first AI. (Fig. 1). Each mastitic cow was systematically allocated to one of the four experimental groups (I-IV). In other words, the first mastitis case was allocated to the first treatment group, the second case to the second group, the third to the third, the fourth to the fourth, and the fifth mastitis case was then allocated to the first treatment group, and so on until each treatment group contained 60 cows. Sample size calculation was based on the study of Lents et al. [34]. Clinical cases of mastitis caused by yeasts or Prototheca spp. were excluded from the experiment. One control healthy cow to every four mastitic cows with no more than 14 days between calving were included on each farm. On day 1, 7, and 21 of diagnosed mastitis, quarter milk samples from affected cows were collected aseptically in order to perform microbiological culturing 


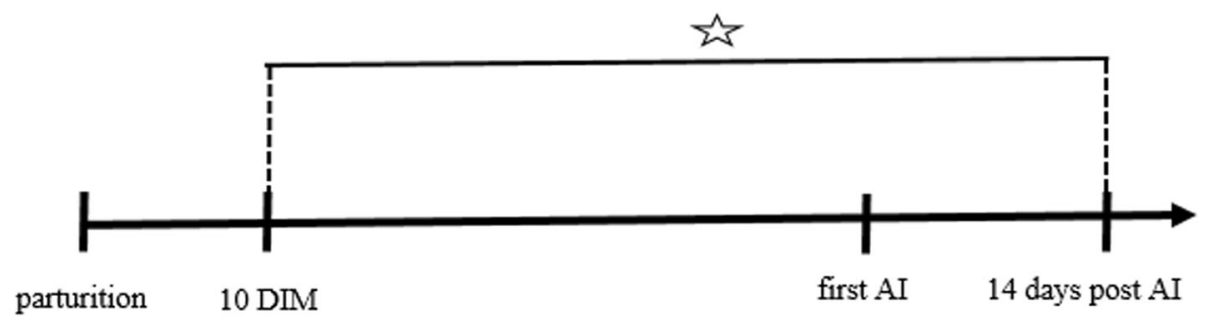

Fig. 1 General experiment design. DIM: days in milk. Al: artificial insemination. 岤: period in which clinical mastitis was monitored for

and antibiotic susceptibility assessment. Milk samples collected on day 21 of treatment were also analyzed for somatic cell counts (Fossomatic 90, Foss, Denmark). Bacteria were identified following the generally accepted procedure of agar plate milk microbiology test [35]. Antimicrobial susceptibility testing was performed using the disc diffusion method (Kirby-Bauer method) [36] on Mueller-Hinton agar according to Clinical and Laboratory Standards Institute guidelines. The antimicrobials discs investigated included i.a. $30 \mu \mathrm{g}$ cefquinome, $2 \mu \mathrm{g}$ clindamycin, $30 \mu \mathrm{g}$ neomycin and 20/10 $\mu$ g amoxicillin with clavulanic acid [35, 36].

The effectiveness of antibiotic therapy was assessed by observing the reduction in clinical symptoms (hot and swollen quarters) and the appearance of macroscopic milk changes (clots, watery secretion, serum purulent, or purulent secretion) during the first three to 7 days of therapy. The CM was considered cured when clinical signs had diminished by day 7 of therapy and a lack of clinical signs and bacteriological cure were observed on day 21. If more than one quarter was affected, the cow was considered cured only when all affected quarters lacked clinical and bacteriological observations. In some cases, antibiotic therapy was continued (with the second or next antibiotic treatment being described as prolonged treatment), which means the same antibiotic as used earlier in the particular treatment was applied three times every 12 hours on days 7 and/or 14 day of treatment. Cows were considered as not having recovered if, on day 21 after diagnosis, despite the multiple administrations of intramammary antibiotic, microorganisms could be cultured from milk samples, and if somatic cell counts in the milk were above $800,000 / \mathrm{ml}$.

When udder inflammations were detected in the control group, the affected cows were excluded, each being replaced by another healthy cow with a similar calving date and without clinical mastitis and low somatic cell counts in milk $(<400,000 / \mathrm{ml})$. In the experimental groups, additional therapy was provided alternately and randomly at the onset of antibiotic therapy. The additional therapy consisted of a single intramuscular injection of antioxidant Se and vitamin supplements at the dose recommended by the manufacturers (Table 8).

The investigation of reproduction performance continued until pregnancy was confirmed by per rectum examination, or the cows were culled. The following fertility indices were calculated for both control and experimental:

- conception rate after first AI (percentage of pregnant cows after first AI);

- days open (number of days from calving to next pregnancy);

- number of AIs per conception - i.e., the insemination index (number of AI procedures/pregnancy).

Owing to the fact that the cows were maintained in the routine production cycle after the study the animals were released and continued milk production.

\section{Biochemical analysis}

On days 0 and 7 after the beginning of therapy, blood samples were collected from five cows in each group. Total antioxidant status was determined using a standard test kit (Randox Laboratories, UK, cat. no. NX 2332) and colorimetrically (Epoll 20 spectrophotometer, Poll, Poland). Calibration was made performed following the instructions provided by the manufacturer (Randox Quality Control).

\section{Statistical analysis}

Selected parameters (conception rate after first AI, days open, number of AI per conception) were analyzed by oneway ANOVA using SPSS (IBM SPSS version 24.0). Normality was tested using Kolmogorov-Smirnov analysis, and outliers were removed from the database. The parameters were all normally distributed. Logistic regression was used to estimate odds of calving using maximum likelihood estimation. The ANOVA procedure was used to compare the control vs. treatment groups, control vs. cows with one treatment cycle or prolonged therapy, and control vs. all cows treated with antibiotic. The type of antibiotic was initially included in the model, it was not proved significantly, and therefore was finally excluded from the model. Significant differences between groups within the same parameters $(p<0.05)$ were tested using Tukey's post-hoc test and are indicated using superscripts. Results are presented with the arithmetic average, standard deviation, percentage of samples/animals in groups, and level of significant differences. 


\section{Abbreviations}

NSAID: Nonsteroidal anti-inflammatory drug; ROS: Reactive oxygen species; CL: Corpus luteum; CM: Clinical mastitis; DIM: Days in milk; CR: Conception ratio; DO: Days open; NSC: Number of services per conception; Al: Artificial insemination; TAS: Total antioxidant status; SCC: Somatic cell counts; FT: First treatment; PRO: Prolonged treatment; Qr: Quarters; S. aureus: Staphylococcus aureus; CNS: Coagulase-negative staphylococci; G-: Gram-negative bacteria; Str. sp.: Streptococcus species; S. agalactiae: Streptococcus agalactiae; S. uberis: Streptococcus uberis; E. coll: Escherichia coli; PGF2a: Prostaglandin $F_{2 a}$

\section{Acknowledgements}

The authors would like to thank the staff of the Department of Reproductive and Mammary Gland Pathophysiology at the National Veterinary Research Institute, Pulawy for their help performing laboratory analysis. We also thank Yulianri Rizki Yanza, who assisted in statistical analyses. The study was supported by the Ministry of Science and Higher Education's Regional Initiative Excellence framework, 2019-2022, Project no. 005/RID/2018/19.

\section{Authors' contributions}

SS and MG conceived and designed the study. SS collected the data. SS, MG, AC, MSS performed the analyses. SS and KL drafted the manuscript. MSS and AC provided intellectual input, AKP provided intellectual input and language correction, and $\mathrm{HH}$ provided the statistical description. All authors contributed to the interpretation of the data and the writing and editing of the manuscript. The author (s) read and approved the final manuscript.

\section{Funding}

This study was financed by a grant from the Polish Ministry of Science and Higher Education (Number 2P 06 K 048 26). The funding institution financed medication (antibiotics and supporting medicines), laboratory analysis, labor, and veterinarians. The funding institution had no role in the design of the study; in the collection, analysis, and interpretation of data; or in the writing of the manuscript.

\section{Availability of data and materials}

The datasets used and analyzed in the current study are available from the corresponding author on reasonable request.

\section{Ethics approval and consent to participate}

The study was performed with the approval of the Local Ethics Committee for Experiments on Animals of Faculty of Animal Breeding and Biology, Bydgoszcz, Poland (license no. 59/2012). The farm owners gave informed consent in writing

\section{Consent for publication}

Not applicable.

\section{Competing interests}

The authors declare that they have no competing interests.

\section{Author details}

${ }^{1}$ Department of Internal Diseases and Diagnosis, Faculty of Veterinary Medicine and Animal Science, Poznań University of Life Sciences, Poznań, Poland. ${ }^{2}$ Veterinary Centre, Nicolaus Copernicus University, Torun, Poland. ${ }^{3}$ Department of Preclinical Sciences and Infectious Diseases, Faculty of Veterinary Medicine and Animal Science, Poznań University of Life Sciences, Wolynska 35, 60-637 Poznan, Poland. ${ }^{4}$ Department of Animal Nutrition, Faculty of Veterinary Medicine and Animal Science, Poznań University of Life Sciences, Poznań, Poland. ${ }^{5}$ Department of Animal Nutrition, West Bengal University of Animal and Fishery Sciences, Kolkata, India.

\section{Received: 11 April 2019 Accepted: 4 March 2020}

Published online: 30 March 2020

\section{References}

1. Norman HD, Wright JR, Hubbard SM, Miller RH, Hutchison JL. Reproductive status of Holstein and Jersey cows in the United States. J Dairy Sci. 2009; 92(7):3517-28.

2. Dillon P, Berry DP, Evans RD, Buckley F, Horan B. Consequences of genetic selection for increased milk production in European seasonal pasture based systems of milk production. Livest Sci. 2006;99:141-58.
3. Macdonald KA, Verkerk GA, Thorrold BS, Pryce JE, Penno JW, McNaughton $L R$, et al. A comparison of three strains of Holstein-Friesian grazed on pasture and managed under different feed allowances. J Dairy Sci. 2008; 91(4):1693-707.

4. Rearte R, LeBlanc SJ, Corva SG, de la Sota RL, Lacau-Mengido IM, Giuliodori MJ. Effect of milk production on reproductive performance in dairy herds. J Dairy Sci. 2018;101(8):7575-84.

5. DeJarnette JM, Nebel RL, Marshall CE. Evaluating the success of sex-sorted semen in US dairy herds from on farm records. Theriogenology. 2009;71(1): 49-58.

6. Lucy MC. The bovine dominant ovarian follicle. J Anim Sci. 2007;85(13 Suppl):E89-99.

7. Wilson DJ, Grohn YT, Bennett GJ, González RN, Schukken YH, Spatz J. Milk production change following clinical mastitis and reproductive performance compared among J5 vaccinated and control dairy cattle. J Dairy Sci. 2008; 91(10):3869-79.

8. Chagas LM, Bass JJ, Blache D, Burke CR, Kay JK, Lindsay DR, et al. Invited review: New perspectives on the roles of nutrition and metabolic priorities in the subfertility of high-producing dairy cows. J Dairy Sci. 2007:90(9):4022-32.

9. Huszenicza G, Jánosi S, Kulcsár M, Kóródi P, Reiczigel J, Kátai L, et al. Effects of clinical mastitis on ovarian function in post-partum dairy cows. Reprod Domest Anim. 2005;40(3):199-204.

10. Schrick FN, Hockett ME, Saxton AM, Lewis MJ, Dowlen HH, Oliver SP. Influence of subclinical mastitis during early lactation on reproductive parameters. J Dairy Sci. 2001;84(6):1407-12.

11. Korzekwa A, Jaroszewski JJ, Bogacki M, Deptula KM, Maslanka TS, Acosta TJ, et al. Effects of prostaglandin $\mathrm{F}$ (2alpha) and nitric oxide on the secretory function of bovine luteal cells. J Reprod Dev. 2004;50(4):411-7.

12. Nakamura T, Sakamoto K. Reactive oxygen species up-regulates cyclooxygenase-2, p53, and Bax mRNA expression in bovine luteal cells. Biochem Biophys Res Commun. 2001;284(1):203-10.

13. Lee SH, Acosta TJ, Yoshioka S, Okuda K. Prostaglandin F(2alpha) regulates the nitric oxide generating system in bovine luteal endothelial cells. J Reprod Dev. 2009;55(4):418-24.

14. Endo T, Aten RF, Leykin L, Behrman HR. Hydrogen peroxide evokes antisteroidogenic and antigonadotropic actions in human granulosa luteal cells. J Clin Endocrinol Metab. 1993;76(2):337-42.

15. Moore DA, Cullor JS, Bondurant RH, Sischo WM. Preliminary field evidence for the association of clinical mastitis with altered interestrus intervals in dairy cattle. Theriogenology. 1991;36(2):257-65.

16. Santos JE, Cerri RL, Ballou MA, Higginbotham GE, Kirk JH. Effect of timing of first clinical mastitis occurrence on lactational and reproductive performance of Holstein dairy cows. Anim Reprod Sci. 2004;80(1-2):31-45.

17. Fourichon C, Seegers H, Bareille N, Beaudeau F. Effects of disease on milk production in the dairy cow: a review. Prev Vet Med. 1999;41(1):1-35.

18. Milne MH, Biggs AM, Barrett DC, Young FJ, Doherty S, Innocent GT, et al. Treatment of persistent intramammary infections with Streptococcus uberis in dairy cows. Vet Rec. 2005;157(9):245-50.

19. Malinowski E, Lassa H, Kłossowska A, Smulski S, Markiewicz H, Kaczmarowsk M. Etiological agents of dairy cows' mastitis in western part of Poland. Pol J Vet Sci. 2006;9(3):191-4.

20. Markiewicz HM, Gehrke M, Malinowski E. Wpływ witamin C i E oraz selenu na aktywność leukocytów i status antyoksydacyjny krwi krów w okresie puerperium. Medycyna Wet. 2007:1288-91.

21. Weiss WP, Hogan JS. Effects of dietary vitamin C on neutrophil function and responses to intramammary infusion of lipopolysaccharide in periparturient dairy cows. J Dairy Sci. 2007:90(2):731-9.

22. Michal JJ, Heirman LR, Wong TS, Chew BP, Frigg M, Volker L. Modulatory effects of dietary beta-carotene on blood and mammary leukocyte function in periparturient dairy cows. J Dairy Sci. 1994;77(5):1408-21.

23. Calderon F, Chauveau-Duriot B, Pradel P, Martin B, Graulet B, Doreau M, et al. Variations in carotenoids, vitamins $A$ and $E$, and color in cow's plasma and milk following a shift from hay diet to diets containing increasing levels of carotenoids and vitamin E. J Dairy Sci. 2007;90(12):5651-64.

24. Kawashima C, Kida K, Schweigert FJ, Miyamoto A. Relationship between plasma beta-carotene concentrations during the peripartum period and ovulation in the first follicular wave postpartum in dairy cows. Anim Reprod Sci. 2009;111(1):105-11.

25. Malinowski E, Dudko P, Kłossowska A, Markiewicz H, Szalbierz M, Branicki T, et al. Efektywność Lydium-KLP w leczeniu mastitis subclinica. Medycyna Wet. 1995;51:156-9. 
26. Malinowski E, Lassa $H$, Smulski S, Klossowska A, Kaczmarowski M. Antimicrobial susceptibility of bacteria isolated from cows with mastitis in 2006-2007. B Vet I Pulawy. 2008;52(4):565-72.

27. Green MJ, Green LE, Cripps PJ. Low bulk milk somatic cell counts and endotoxin-associated (toxic) mastitis. Vet Rec. 1996;138(13):305-6.

28. Wagner SA, Apley MD. Effects of two anti-inflammatory drugs on physiologic variables and milk production in cows with endotoxin-induced mastitis. Am J Vet Res. 2004;65(1):64-8.

29. Scenna FN, Hockett ME, Towns TM, Saxton AM, Rohrbach NR, Wehrman ME, et al. Influence of a prostaglandin synthesis inhibitor administered at embryo transfer on pregnancy rates of recipient cows. Prostaglandins Other Lipid Mediat. 2005;78(1-4):38-45.

30. Ahmadzadeh A, Frago F, Shafii B, Dalton JC, Price WJ, McGuire MA. Effect of clinical mastitis and other diseases on reproductive performance of Holstein cows. Anim Reprod Sci. 2009:112(3-4):273-82.

31. Barker AR, Schrick FN, Lewis MJ, Dowlen HH, Oliver SP. Influence of clinical mastitis during early lactation on reproductive performance of Jersey cows. J Dairy Sci. 1998;81(5):1285-90.

32. Markiewicz H, Malinowski E, Kuzma K, Smulski S, Kaczmarowski M. Activity of neutrophils in the blood of healthy and mastitic cows. Medycyna Wet. 2006; 62(11):1288-91.

33. Wathes DC, Taylor VJ, Cheng Z, Mann GE. Follicle growth, corpus luteum function and their effects on embryo development in postpartum dairy cows. Reprod Suppl. 2003;61:219-37.

34. Lents CA, Wettemann RP, Paape MJ, Vizcarra JA, Looper ML, Buchanan DS, Lusby KS. Efficacy of intramuscular treatment of beef cows with oxytetracycline to reduce mastitis and to increase calf growth. J Anim Sci. 2002;80(6):1405-12.

35. Clinical and Laboratory Standards Institute. Performance standards for antimicrobial disk and dilution susceptibility tests for bacteria isolated from animals. Wayne: CSLI Supplement M31-S1; 2004.

36. Clinical and Laboratory Standards Institute. Performance standards for antimicrobial susceptibility testing. Wayne: CSLI Twenty-first International Supplement M100-S-21;2011.

\section{Publisher's Note}

Springer Nature remains neutral with regard to jurisdictional claims in published maps and institutional affiliations.

Ready to submit your research? Choose BMC and benefit from:

- fast, convenient online submission

- thorough peer review by experienced researchers in your field

- rapid publication on acceptance

- support for research data, including large and complex data types

- gold Open Access which fosters wider collaboration and increased citations

- maximum visibility for your research: over $100 \mathrm{M}$ website views per year

At $\mathrm{BMC}$, research is always in progress.

Learn more biomedcentral.com/submissions 